\title{
CORPORATE SOCIAL RESPONSIBILITY IN DISASTER RISK MANAGEMENT: A STUDY ON SOME SELECTED PRIVATE COMMERCIAL BANKS OF BANGLADESH
}

\author{
MD. ABDUS SATTAR
}

Assistant Professor, Sociology, Open School, Bangladesh Open University, Gazipur, Bangladesh

ABSTRACT
The central aim of this paper is to find out, the CSR activities of private commercial banks and their
concentration in Disaster Risk Management. No doubt, Bangladesh is a disaster potential country. This article tries to
discover the disasters that occur in Bangladesh and general Corporate Social Responsibility (CSR), initiatives of private
commercial banks for the society. It also tries to find out the CSR activities of, such type of banks in disaster risk
management. This paper discusses that, most of the banks have no enormous role in disaster risk management, except
donating some blankets to the cold affected poor people and funding to a particular relief fund, as relief activity. They
never follow the cycle of disaster management. Most of the banks take initiatives, for their clients under CSR initiatives.
This descriptive analysis is based on qualitative methods.
KEYWORDS: Corporate Social Responsibility, Disaster Risk Management and Private Commercial Bank

Received: Aug 11, 2017; Accepted: Aug 30, 2017; Published: Sep 12, 2017; Paper Id.: IJEEFUSOCT20172

\section{INTRODUCTION}

Bangladesh is well known disaster prone country. Every year, on average Bangladesh has to face various types of disaster. Generally, two types of disasters are seen, i.e., natural disaster and man-made disaster. Natural disasters, including cyclone, flood, earthquake, riverbank erosion, drought, tornado, thunderstorm, landslide, etc. occur due to adverse behavior of nature, whereas, man-made disasters are the result of human activities. Bangladesh has the highest vulnerability to disaster, over the world. Various factors make the country susceptible to disasters. These factors are social, economic, demographic, cultural, political, ethical, geographical, etc. Frequency of occurring disaster is increasing day by day, due to the changes in climate variables. Lack of awareness among the people, social inequality, lack of social mobility, limitation in social safety net, corruptions, unequal distribution of wealth, poverty, Agra-based economy, lower per capita income, population growth, density, priority of children and old aged people in age composition, restriction in movement of women in disaster situation, lack of political stability and geophysical location of this region, increase the enormity of disaster risk. On the other hand, the tremendous increasing of global temperature increases the frequency of natural disaster. As being a country situated in the downstream, Bangladesh is supposed to flood risk due to rain, cutting forests and mountains in upper stream countries and raising the level of sea water, due to glaciers melting in the northern and southern hemispheres. Global warming increases the rate of occurrence of cyclone and cyclonic storm, over the world. As a result, Bangladesh has to face such type of disaster. Temperature increasing due to carbon emissions, is the cause for lessening of moisture in the soil, and creates a drought situation. To manage the risk of disaster, it is needed to engage every sector to take initiatives separately. These separate initiatives can be combined with the 
platform of Disaster Risk Management (DRM), to lessen of the sufferings of the people. In this case, the private commercial bank of Bangladesh may play a significant role in disaster risk management, by taking activities under their CSR initiatives.

\section{Most Occurring Disasters in Bangladesh \\ Flood}

Floods have had an impact on society, from time immemorial (Kundzewicz and Takeuchi 1999). Floods are the most significant natural hazard, causing suffering to a large amount of people and damage to property in Bangladesh. Abnormal floods submerge about 60 percent of the land, damage crops, and properties, disrupt economic activities and causes diseases and loss of life (Nasreen 2004). Rainfall is one of the main causes for flooding in Bangladesh. Most of the floods that occurred in Bangladesh, have turned into catastrophe due to huge water flow from the upstream point, and at the same time, regional rainfall acted as an auxiliary factor, which accelerates the situation to be worse (Elahi 1988). For example, the flood of 1987 was predominately caused by local rainfall (Miah 1988). The three major river catchment areas are also, one of the rainiest areas of the world, where every year on average the Ganges basin receives $140 \mathrm{~cm}$, Brahmaputra basin receives $140 \mathrm{~cm}$ and Meghna basin receives $400 \mathrm{~cm}$ rainfall, respectively (Mirza 1998). The low land area is another cause for flooding in Bangladesh. About one half of the land area in Bangladesh is at an elevation of less than 8 meters, above sea level. Up to $30 \%$ of the country has been covered by flood waters. An area along coastlines (coastal region of Bangladesh), become subject to flooding as a result of cyclonic storms and unusual high tides. Long term subsidence and rising sea level, as a result of global warming can lead to the encroachment of the sea onto the land. Dam and embankment failure, make flood vulnerability. Human constructed dam/embankments are built for water storage, generation of electrical power and flood control. Bangladesh had experienced an enormous flood in 1954, 1955, 1962, 1963, 1968, 1969, 1970, 1971, 1974, 1987, 1988, 1998, 2004, 2007 and 2017. Between these years, the flooding of 1988, 1998 and 2017 are abnormal in nature, and caused enormous losses and damages.

\section{Cyclone}

Any typhoons with storms is called 'Cyclones' in English, if they occur in the Indian Ocean. These cyclones generally occur in early summer (April-May) or late rainy season (October-November). Cyclones originate from low atmospheric pressure, over the Bay of Bengal. The coastal regions of Bangladesh, including Satkhira, Khulna, Bagerhat, Barguna, Patuakhali, Pirojpur, Bhola. Noakhali, Chittagong and Cox's Bazar, are subject to damaging, due to cyclone, almost every year. These cyclones, which affect the near coastal regions, also affect the closest regions of Gopalgonj, Barisal etc. Therefore, Bangladesh is one of the most cyclone prone areas, over the world.

During the years 1797 to 2009, Bangladesh has been hit by 61 severe cyclones, 34 of which were accompanied by storm surges. Between 1877 and 1995, Bangladesh was affected by 154 cyclones, including 43 severe cyclonic storms, 43 cyclonic storms, 68 tropical depressions ${ }^{1}$ (Indian Meteorological Department 2010). The Indian Meteorological Department (IMD) is responsible for tracking tropical storms and cyclones, in South Asia, including the Bay of Bengal. Since 1995, five severe cyclones hit the coast of Bangladesh in May 1997, September 1997, May 1998, November 2007 and May 2009. On an average, a severe cyclone strikes Bangladesh once in every three years (GOB 2009).

\footnotetext{
${ }^{1}$ Tropical storms are classified based on the observed maximum sustained surface wind measured at a height of $10 \mathrm{~m}$ averaged over 3 minutes as follows: Super Cyclonic Storm (greater than $220 \mathrm{~km} / \mathrm{hour}$ ), very severe cyclonic storm (119-220 km /hour), severe cyclonic storms (90-119 km/hour), cyclonic storms (60-90 km/hour), Deep depression (51-59 km/hour), Depression (32-50 km/hour) (Indian Meteorological Department, 2010).
} 
The cyclone of 1970 and storm surge took away about 5,00,000 people, and damaged the equivalent of about US\$ 42.5 billion in crops and property, and the catastrophic cyclone of 1991 killed about 1,45,000 people, the super cyclone Sidr 2007 killed about 3,406, with 1,001 still missing, and over 55,000 people sustaining physical injuries. Total damage and losses caused by the cyclone, to be Bangladesh Taka (BDT) 115.6 billion (US\$ 1.7 billion). Another cyclone with severe storm surge, Aila 2009 killed about 330 people, 1 million people homeless and left damages, which totaled \$40.7 million (GOB, 2009). Shaw et al. (2010), stated that, in Bangladesh, an estimated 20 million people were at risk of post disaster diseases due to Aila.

\section{Drought}

Drought is a very well known natural disaster to the people of Bangladesh. For drought, average rainfall becomes less during the critical growth stages of crops, and they suffer from soil moisture deficits. Drought stress caused by higher evapo-transpiration and reduced rainfall, may override any growth benefits from the higher CO2 levels, unless irrigation can be stepped up to compensate. During a drought, a heavy loss of Aman production affects the farm economy.

Drought occurs when there is less rainfall for a prolonged period, causing marked hydrological imbalance. It leads to parching of the ground, withering of vegetation. Although, generally associated with semiarid and arid regions, drought can occur in areas that normally adequate rainfall, with high inter-annual variability. Under drought conditions, evaporation and evapo-transpiration exceed normal levels, and if continued for an extended period, it might severely affect agriculture production (Rasheed 2008). A drought year in Bangladesh is identified, when more than 20 percent of the area of the country is affected by drought (SAARC 1992). In Bangladesh there were severe droughts in 1951, 1957, 1958, 1962, 1966, 1972, 1979, 1989 and 1999 (WARPO 2000). The percentage of drought affected areas were $31.63 \%$ in 1951 , 46.54\% in $1957,37.47 \%$ in $1958,22.39 \%$ in $1961,18.42 \%$ in $1966,42.48 \%$ in 1972 and $42.04 \%$ in 1979 . During 1981 and 1982 , droughts affected the production of the monsoon crops only. During the last 50 years, Bangladesh suffered about 20 drought conditions. The drought condition in northwestern Bangladesh, in recent decades had led to a shortfall of rice production, of 3.5 million tons in the 1990s (ASB 2003).

\section{Riverbank Erosion}

Riverbank erosion is a well known disaster in Bangladesh. As a silent disaster, this disaster can be found in the flood prone area of this country. Among the disasters in Bangladesh, riverbank erosion has the most negative impact on human settlement and river morphology. Approximately, loss due to erosion in $\$ 500$ million dollars per year and about 3 , 00,000 people lost their homestead and took shelter on various roads, embankment and government khas land (ASB 2003).

\section{Earthquake}

Bangladesh is the highest earthquake vulnerable area. The delta islander Bangladesh is earthquake vulnerable, because of its geographic location and geologic formation of the earth. Bangladesh is well within the tropics, bounded by latitude $20^{\circ} 34^{\prime} \mathrm{N}$ to $26^{\circ} 38^{\prime} \mathrm{N}$ and longitude $88^{\circ} 01^{\prime} \mathrm{E}$ to $92^{\circ} 41^{\prime} \mathrm{E}$. This country's geographic location is delimited by three tectonic plate boundaries, such as-Indian plate, Eurasian plate and Burmese Plate. Many times, this Bengol region has faced earthquake of various magnitude, which is also potential for earthquake hazards, according to its recorded history. In 1548, 1742, 1885, 1889, 1918, 1930, 1934, 1997, 1999 and 2003, this region felt strong, moderate and small earth shaking (Rahman 2009). 


\section{Disaster Risk Management (Drm)}

DRM means, every activity related to reduced risk of extreme climatic hazards, technological hazards or human induced hazards through making decisions, organizational behavior and overall capacities of the population, and responsible stakeholders to recover from these hazardous events, by implementing policies to lessen risk, strategies to adapt changing climate and coping with the future extremeness of climate. As UNISDR (2004) stated that, disaster risk management means, the systematic process of using administrative decisions, organization, operational skills and capacities to implement policies, strategies and coping capacities of the society and the communities, to lessen the impacts of natural hazards and related environmental and technological disasters. This comprises of all forms of activities, including structural and non-structural measures, to avoid (prevention), or to limit (mitigation and preparedness) adverse effects of hazards.

Disaster risk management is the composite of disaster risk reduction (managing hazards through preparedness, mitigation and prevention measures whilst working to build resilience); climate change adaptation (actions taken to cope, evolve or profit from changes in climate); sustainable natural resource management (the management of ecosystems resulting in direct benefits and protective measures of livelihoods); social protection (provision of income or transfers targeting disadvantaged people in order to address their vulnerability) and prevention under-nutrition (tackling the underlying and basic causes of under-nutrition, commonly related to interventions in health, water, sanitation and hygiene, food security, nutrition, and maternal and infant care practices).

Garatwa and Bollin (2002), defined disaster risk management, as a series of actions (programs, projects and/or measures) and instruments, expressly aimed at reducing disaster risk in endangered regions, and mitigating the extent of disasters. They also describe disaster risk management, which includes risk assessment, disaster prevention and mitigation and disaster preparedness. It is used in the international debate, to underscore the current trend of taking a proactive approach to hazards, posed by extreme natural phenomena. The intention is a comprehensive reduction in disaster risk, accounting for all the factors that contribute to risk (risk management), as opposed to a focus on each individual danger.

Disaster Risk Management is a process of some measures, which include three phases. These phases focus risk analysis/assessment, prevention and preparedness in before/pre disaster phase; emergency aid/assistance, rescue, relief and sheltering in, during disaster phase and finally reconstruction, recovery and rehabilitation in after/post disaster phase. Sometimes, disaster risk management focusing only the pre/before disaster analysis of risk, prevention of the situation and taking preparedness measures to manage risk. Freeman et al. (2003), focused only two phases of disaster risk management. They eliminate during disaster phase and merge it on the post disaster phase. In this case, the disaster risk management depends on the process of pre-disaster and post disaster phase, of disaster management. The pre disaster measures of disaster risk management includes, the identification of risk, the way of risk mitigation, risk transfer by insurance and other initiatives \& preparedness. On the other hand, the post disaster risk management phase includes, emergency response, rehabilitation and reconstruction.

\section{Disaster Risk Management Cycle}

Disaster risk management cycle, consists of four phases: Mitigation and Preparedness in the pre-disaster stage and Response and Recovery (Rehabilitation and Reconstruction) in the post-disaster stage. Mitigation phase refers prevention phase. Mitigation reduces and limits the destructive and disruptive effects of hazards on the elements at risk. Measures the 
range from the physical, such as engineering works like bridges, protective dikes, embankments and safe building design to the non-structural interventions, such as community risk assessment, community risk reduction planning, public awareness, food security programs, group savings, cooperatives, crop insurance, strengthening community disaster management organizations and advocacy on disasters and developments issues, legislation and land use zoning. Mitigation and prevention interventions are directly linked to development planning. "Disaster mitigation is intrinsic to sustainable development" (Twigg et al. 2000).

Activities and measures for ensuring an effective response to the impact of hazards are classified as "Preparedness", "Response" and "Recovery". Preparedness involves measures taken in anticipation of a disaster, to ensure that, appropriate and effective actions are taken during the emergency, such as the systems for early warning, coordinative and institutional arrangements, evacuation and emergency operations management, public awareness, disaster and evacuation drills and stockpiling. "Response" phase includes the measures to ensure survival and prevent further deterioration of the situation. These measures include search and rescue, immediate repair and restoration of critical facilities and utilities, conduct of damage needs and capacity assessment, food and non-food relief assistance, emergency medical assistance, evacuation center management and networking."Recovery" phase consists of two important stages of "Rehabilitation" and "Reconstruction". "Rehabilitation" and "Reconstruction" phase, considerations of disaster risk reduction should form the foundations for all activities. Taking appropriate measures, based on the concept of disaster risk management in each phase of the disaster risk management cycle, can reduce the overall disaster risk.

\section{Corporate Social Responsibility (Csr)}

The definitions of Corporate Social Responsibility (CSR) are numerous and varied (Garriga and Mele 2004; Maon, Lindgreen and Swaen 2008). Kotler and Lee (2005:5) stated that, CSR as an organization's commitment to improve community well-being, by way of discretionary business practices and contributions of the organization's resources. Organizations can contribute to sustainable economic development, by working together not only to their employees and families, but also the local community, and society at large, to improve their quality of life (Holme and Watts 2000). From a CSR perspective, organizations may be instrumental in the construction of a better world (Friedman and Miles 2002).

The researchers (Brammer and Millington 2003; Lindgreen, Swan and Johnston 2008; Vogel 1978 \& 2004) stated that, during the past two decades, Corporate Social Responsibility (CSR) has achieved business prominence, largely as a result of activities by pressure groups, as well as the emergence of the market for virtues, which includes socially responsible investments and creates pressures to adopt Corporate Social Responsibility (CSR) initiatives. Many organizations have their own CSR programs (e. g., Gupta and Chary 2006; Rajshekar and Iyengar 2004), implement ethical codes of conduct and charters (Campbell 2006; Kolk and Van Tulder 2002) strong collaboration with nongovernmental organizations (NGOs) (Nijhof, de Bruijn, and Honders 2008; Powell-Smith, 2005) and international federations (Wills, 2002) or within CSR networks (e. g., Business for Social Responsibility; CSR Europe), or attempt to reconsider value and ethical issues, associated with their business model and organizational culture (Joyner and Payne 2002).

\section{The United Nations (UN) Explains and Defines Corporate Social Responsibility as follows}

The social responsibility of the private sector goes beyond the sector's day-to-day operation, of producing a certain range of products and services, in the most efficient and economical manner. The social responsibility of the private sector (also referred to as corporate social responsibility), concerns the relationships of a company not just with its clients, 
suppliers and employees, but also with other groups, and with the needs, values and goals of the society in which it operates. All these groups can be regarded as stakeholders in the company. Stakeholders can be identified as, those individuals or groups of individuals, that have an interest, or take an interest, in the behavior of the company both within and outside its normal mode of operation. They therefore, establish what the social responsibility of the company entails or, at least, how they perceive it to be (UN 2000).

\section{OBJECTIVE OF THE STUDY}

\section{The Objectives of this Study Are}

- $\quad$ To present a brief statement of the banking structure of Bangladesh

- To know the general activities under CSR initiatives of private commercial banks of Bangladesh

- $\quad$ To suggest some recommendations, to take DRM based CSR initiatives

\section{METHODOLOGY}

The banking sector of Bangladesh is not too small. There are about 39 private commercial banks in Bangladesh. Most of the private commercial banks have their general CSR activities. Among the private commercial banks, I have selected 12 of the banks as sample, for conducting studies. The sample banks for study have been selected randomly. This paper is a descriptive study in nature, based on secondary data and information. The secondary data and information have been collected from scholars' and researchers' published books, articles, periodical and web site. The data and information on CSR of banks have been collected from banks' websites, annual reports, periodicals, etc. The data and information have been analyzed critically, in order to make the study more informative, useful and acceptable to the readers. The whole process of this present study was based on qualitative methods.

\section{RESULTS AND DISCUSSIONS}

Banking Structure in Bangladesh

There are six types of banks in Bangladesh, namely central bank, state owned commercial banks, scheduled state owned specialized bank, non-scheduled state owned commercial bank, private commercial bank and foreign commercial bank (Table 1, Appendix). There are 39 private commercial banks in Bangladesh (Table 2, Appendix).

\section{General CSR Activities of Private Commercial Banks in Bangladesh}

Corporate Social Responsibility of private commercial banks, emphasizes on education, health, nutrition, population, water, sanitation, hygiene, education, climate change, environment, housing and heritage of art and culture sports etc. (Table 3, Appendix). Most of the banks donate to the Prime Minister's Relief Fund. They work for health sector, by providing infrastructural development, by giving air conditioner, donate ambulance, cash for building structure, providing scholarships for nursing course students, organize training and workshop on health related issues, donate and working with the children with autism, organize training for the children with special needs etc. Some of the banks also take initiatives, to improve reproductive health, maternal and neonatal, child health and nutritional status, reduce vulnerability to communicable diseases, combat non-communicable diseases and enhance quality of life of disadvantages and socially excluded populations. Most of the banks take initiative for the development of education sector, under their CSR activities. Through education program, they engage people to build self-respect and capabilities to make career and life changing journey. They provide scholarships, donate for structural development, arrange Olympiad for the students, 
conduct predictive research, enable information sharing and provide education, training, simulation sessions and situation reports to both their staff and communities, to improve preparedness. Private commercial banks of Bangladesh play an important role, to provide cultural activities, giving sponsorship for arranging for games, sports etc. Sometimes, they provide for housing or subsidize house rent. These banks contribute to PM's Relief Fund, giving award, trust fund, games, making documentary on liberation war and conservation of natural resources. Sometimes, they financed for communication, telecommunication, bridge, road and highways etc. Disaster management activities, under their CSR initiatives of these private commercial banks are limited in relief, and sometimes for rehabilitation. The relief activities of these banks are limited in blanket donation, for cold affected people, relief donation for flood affected people and very few banks sometimes emphasize on disaster, environment and climate change (DECC) program to enhances institutional capacity to respond to natural disasters, builds competence at the community level, on disaster preparedness and increases coping ability during natural disasters, with preventive and adaptive strategies. They mention that, in the long run, all these measures are aimed at reducing vulnerability of the exposed population. They trained women from disaster prone rural area on trauma counseling, to enhance their resilience to climate change risks and other stresses. Private commercial banks' emergency relief and rehabilitation support help communities, restore their lives and livelihoods.

\section{Initiatives for Disaster Risk Management}

Disaster Risk Management is the composition of mitigation, preparedness, response and recovery. It is important for meaningful disaster management, to emphasize in pre-disaster mitigation and preparedness activities. Although, the national plan for disaster management of the Government of the People's Republic of Bangladesh, emphasizes three broad based strategies (GOB 2010): 1); disaster management would involve the management of both risks and consequences of disasters, that would include prevention, emergency response and post-disaster recovery; 2) community involvement, for preparedness program for protecting lives and properties would be a major focus. Involvement of local government bodies would be an essential part of the strategy. Self-reliance should be the key for preparedness, response and recovery and 3) non-structural mitigation measures, such as community disaster preparedness training, advocacy and public awareness must give a high priority; this would require an integration of structural mitigation, with non-structural measures. But, the private commercial banks emphasize, only on the relief based disaster response. They donate to the Prime Minister's Relief Fund, for disaster affected people and provide blankets for cold affected poor people. In the long run, they do not have any broader strategies, for pre disaster risk management to post disaster consequence reduction.

Table 1: Disaster Management Initiatives of Private Commercial Banks under DRM Cycle

\begin{tabular}{|l|l|l|c|}
\hline \multicolumn{2}{|c|}{ DRM initiatives taking by banks } & \% of banks \\
\hline \multirow{2}{*}{ Pre-disaster } & Mitigation & $* *$ & 0 \\
\cline { 2 - 4 } & Preparedness & $* *$ & 05 \\
\hline \multirow{3}{*}{ During and post disaster } & \multirow{2}{*}{ Response } & Relief & 80 \\
\cline { 2 - 4 } & \multirow{2}{*}{} & Aid/Donation & 05 \\
\cline { 2 - 4 } & \multirow{2}{*}{ Recovery } & Rehabilitation & 05 \\
\cline { 2 - 4 } & & Reconstruction & 05 \\
\hline
\end{tabular}

Sources: Annual Report of Sample Banks in Different Years

The above table 4 shows that, the overwhelming majority of 80 percent private commercial banks emphasizes on response phase, especially for relief activities. But, it is important in disaster risk management, to give more emphasize on pre disaster mitigation and preparedness activities, and then on the recovery phase, to normalize the life of the affected community. The table also shows that, no bank has any activity under mitigation phase, to lessen the vulnerability of 
community or society. Sometimes, these banks donate aid/donation for the people as emergency response, which is not remarkable. The preparedness phase is the most important in disaster risk management, but the banks do not take any mentionable initiatives for this, under their CSR. Like preparedness and aid/donation, the recovery activities (rehabilitation and reconstruction) are limited and not perfect.

\section{RECOMMENDATIONS}

The following initiatives may be followed by the private commercial banks, in managing disaster risks under their CSR. These activities are formed, according to disaster risk management (DRM) cycle.

- In mitigation phase, the banks should take some non-structural measures, such as organized awareness building training on implementing the National Building Code and raise awareness about protecting, to build resident in an earthquake hazard prone zone. They should finance for the disaster affected people for small business, without interest and take initiatives through risk insurance, for the small farmers who are vulnerable to disasters. Primarily, they can take the above initiatives for their stakeholder and others. For structural measures, they can make embankment and shelter home associate, with government and NGOs.

- In preparedness phase, the private commercial banks can receive the early warning signals firstly and disseminate it primarily to their clients, and then others with the help of their CSR budget, for taking urgent initiative to rescue the disaster affected people. During a disaster, it may be tough for the government alone, to rescue and evacuate the people who are living in a hazard prone area and in this situation, the help from another source is needed. Therefore, the private commercial banks help the government to evacuate the people. Banks should incorporate this help in their CSR budget.

- In previous results and discussion, we find that, most of the private commercial banks are engaged in providing blankets, for the cold affected poor people and giving money to the Prime Ministers' Relief Fund, as response activities under their CSR. In this phase, they should take more responsibilities for minimizing risk of disaster affected people. After rescuing the people, they should take the initiatives to provide primary health care services and continue health camp. Here, the coordination among the banks and the government is needed, for proper distribution of the relief and donation/aid.

- Recovery is the most important phase in disaster management because; this phase helps the affected people to go to their normal life. In this phase, it is needed to rehabilitate the affected people to their previous occupation or make new opportunities to earn money and survive. In reconstructions, they provide housing loan with zero or minimum interest in the disaster affected people, by enlarging their CSR activities. All of the initiatives can be implemented primarily, for their stakeholders and then others.

\section{CONCLUSIONS}

As a disaster prone country, Bangladesh has to face various types of problem. Disaster is itself not a single problem. It carried other severe social, economic, political, ecological problems, which induced extra vulnerability for the country. It induces extra social vulnerability, including poverty, insecurity in society, corruptions, population displacement, crime and juvenile delinquency, drug addiction, looting, social inequality etc, for the entire society. It also induces economic recession, for the particular society, creates unemployment, maximizes foreign dependency and creates other 
Corporate Social Responsibility in Disaster Risk Management:

political vulnerable situation, locally and globally. Sometimes, serious epidemic diseases could be broken out as an aftermath of disaster. Severe disasters disturb the ecological settings and the natural environment and disrupt bio-diversity. In this case, a total disaster risk management is needed, to minimize such type of vulnerability and risk for the society. This process is not too easy for a single stakeholder e.g., Government. Therefore, it is important to incorporate other potential stakeholders, like commercial banks to minimize the disaster risk. The private commercial banks would be the important stakeholder in disaster risk management. Disaster risk management is not a single phase based program. It should include every phase of disaster management e.g., Mitigation, preparedness, response and recovery. As developing country, Bangladesh needs public-private partnership, to face all of the challenges of climate changes. In this case, the private commercial banks play the most important role, in disaster risk management.

\section{REFERENCES}

1. ASB (2003). Banglapaedia, Dhaka: Asiatic Society of Bangladesh

2. Brammer, S. And A. Millington (2003). The effect of stakeholder preferences, organizational structure and industry, type of corporate community involvement, Journal of Business Ethics, Vol. 45, No. 3, pp. 213-226.

3. Campbell, T. (2006). A human rights approach to developing voluntary codes of conduct for multinational corporations, Business Ethics Quarterly, Vol. 16, No. 2, pp. 255-269.

4. Elahi, K. M. (1988). Socio Economic Impact of Flood and Coexistence with Flood, Bangladesh: Geography, Environment and Development, edited by Elahi, K.M., A. M. Raihan Shrif and A. K. M. Abul Kalam, Bangladesh National Geographical Association, Dhaka, (In Bengali), pp. 55-67.

5. Freeman, P. K.; L. A. Martin; J. L. Bayer; R. Mechler; G. Pflug and K. Warner (2003). Disaster risk management: national systems for the comprehensive management of disaster risk and financial strategies for natural disaster reconstruction. Environment Division, Sustainable Development Department, Inter-American Development Bank. Washington, D.C.: InterAmerican Development Bank.

6. Friedman, A. And S. Miles (2002). Developing stakeholder theory, Journal of Management Studies, Vol. 39, No. 1, pp. 1-21.

7. Garatwa, W. And C. Bollin (2002). Disaster Risk Management: Working Concept. Eschborn: Deutsche Gesellschaft für Technische Zusammenarbeit (GTZ).

8. Garriga, E. And D. Melé (2004). Corporate social responsibility theories: mapping the territory, Journal of Business Ethics, Vol. 53, No. 1-2, pp. 51-71.

9. GOB (2009). Bangladesh Climate Change Strategy and Action Plan 2009, Government of the Peoples' Republic of Bangladesh

10. Gob (2010). National Plan for Disaster Management 2010-2015. Disaster Management Bureau, Ministry Food and Disaster Management, Government of the People's Republic of Bangladesh

11. Gupta, V. And K. Chary (2006). Corporate social responsibility at HP, case study ECCH ref. 706-26-1, ICFAI Center for Management Research, Hyderabad.

12. Holme, R. And P. Watts (2000). Corporate Social Responsibility: Making Good Business Sense, World Business Council for Sustainable Development, Conches-Geneva.

13. Indian Meteorological Department (2010). http://www.imd.gov.in/section/nhac/dynamic/faq/FAQP.htm\#q42 (accessed March $15,2016)$ 
14. Joyner, B. And D. Payne (2002). Evolution and implementation: a study of values, business ethics and corporate social responsibility, Journal of Business Ethics, Vol. 41, No. 4, pp. 297-311.

15. Kolk, A. And R. Van Tulder (2002). The effectiveness of self-regulation: corporate codes of conduct and child labor, European Management Journal, Vol. 20, No. 3, pp. 260-271.

16. Kotler, P. And N. Lee (2005). Corporate Social Responsibility: Doing the Most Good for Your Company and Your Cause, Wiley, Hoboken, NJ.

17. Kundzewicz, Z. W. And K. Takeuchi (1999). Flood protection and management: quo Vadimus?. Hydrological Sciences Journal. (44), pp. 417-432.

18. Lindgreen, A.; V. Swaen and W. J. Johnston (2008). Corporate social responsibility: an empirical investigation of U.S. organizations\|, Journal of Business Ethics,

19. Maon, F.; A. Lindgreen and V. Swaen (2008). Designing and implementing corporate social responsibility: an integrative framework grounded in theory and practice, Journal of Business Ethics, Vol. 45, No. 3, pp. 213-226.

20. Miah, M. M. (1988). Flood in Bangladesh: A Hydro-morphological Study of the 1987 Flood, Dhaka: Academic Publishers, p.9.

21. Mirza, M. M. Q. (1998). Modeling the effects of climate change on flooding in Bangladesh, Unpublished Ph.D. Thesis, International Global change Institute (IGUC), University of Waikato, Hamilton, New Zealand, p. 33.

22. Nasreen, M. (2004). Disaster research: exploring sociological approaches to disaster in Bangladesh. Bangladesh e-journal of Sociology. 2(2). Available at: www.bangladeshsociology.org.

23. Nijhof, A.; de Bruijn, T. And H. Honders (2008). Partnerships for corporate social responsibility: a review of concepts and strategic options, Management Decision, Vol. 46, No. 1, pp. 152-167.

24. Powell-Smith, A. (2005). Finding the right corporate, NGO partnership, Corporate Responsibility Management, Vol. 2, No. 1, pp. 14-15.

25. Rahman, Saidur, M. (2009). Disaster Dictionary (Duryogkosh). Mass-line Printers, Dhaka. pp.129-188.

26. Rajshekar, N. And H. Iyengar (2004). Shell's global social responsibility initiatives, case study ECCH ref. 704-020-1, ICFAI Business School Case Development Centre, Hyderabad.

27. Rasheed, K.B.S (2008). Bangladesh: Natural resource and Environmental Profile, Dhaka: A H Development Publishing House.

28. SAARC(1992)

29. Shaw, R.; J. M. Pulhin and J. J. Pereira (2010). Climate Change Adaptation and Disaster Risk reduction: An Asian Perspective, Emerald Group Publishing Limited.

30. Twigg, J.; C. Benson and M. Myers-research consultants (2000). NGO Initiatives in Risk Reduction: a summary of the research studies for the British Red Cross Society funded by the Department for International Development. C/O The Twigg, John, Charlotte Benson and Mary Myers research consultants.

31. UN (2000). 'Development of guidelines on the role and social responsibilities of the private sector.' Report of the SecretaryGeneral to the Preparatory Committee for the special session of the UN General Assembly on the World Summit for Social Development and beyond (A/AC.253/21). New York: United Nations.

32. UNISDR (2004). Living with Risk -A global review of disaster reduction initiatives, United
Nations Inter-Agency

NAAS Rating: 3.58 
Corporate Social Responsibility in Disaster Risk Management:

Secretariat of the International Strategy for Disaster Reduction, Geneva.

33. Vogel, D. (1978). Lobbying the Corporation: Citizen Challenges to Business Authority, New York, NY: Basic books.

34. Vogel, D. (2004). The Market for Virtue. The Potential and Limits of Corporate Social Responsibility, Washington, D. C. Brookings Institution Press.

35. WARPO (2000). Draft Development Strategy, National Water Management Plan Project, Water Resource Planning Organization, Ministry of Water Resources, Government of Bangladesh, Dhaka.

36. Wills, J. (2002). Bargaining for the space to organize in the global economy: a review of the Accor-F trade union rights agreement, Review of International Political Economy, Vol. 9, No. 4, pp. 675-700.

\section{APPENDIX}

Table 1: Type of Bank in Bangladesh

\begin{tabular}{|c|l|l|}
\hline Serial no. & Type of Bank (s) & Quantity \\
\hline 1. & Central Bank & 01 \\
\hline 2. & State Owned Commercial Bank & 06 \\
\hline 3. & State Owned Specialized Bank (Scheduled) & 02 \\
\hline 4. & State Owned Specialized Bank (Non-scheduled) & 04 \\
\hline 5. & Private, Commercial Bank & 39 \\
\hline 6. & Foreign Commercial Bank & 09 \\
\hline
\end{tabular}

Source: Bangladesh Bank, 2015 and Wikipedia

Table 2: List of Private Commercial Banks in Bangladesh

\begin{tabular}{|l|l|c|l|}
\hline Serial No. & Name of Bank & Serial No. & Name of Bank \\
\hline 1. & AB Bank Limited & 21. & NCC Bank Limited \\
\hline 2. & Al-Arafah Islami Bank Limited & 22. & NRB Bank Limited \\
\hline 3. & Bangladesh Commerce Bank Limited & 23. & NRB Commercial Bank Limited \\
\hline 4. & Bank Asia Limited & 24. & NRB Global Bank Limited \\
\hline 5. & BRAC Bank Limited & 25. & One Bank Limited \\
\hline 6. & Dhaka Bank Limited & 26. & Prime Bank Limited \\
\hline 7. & Dutch Bangla Bank Limited & 27. & Pubali Bank Limited \\
\hline 8. & Eastern Bank Limited & 28. & Shahjalal Islami Bank Limited \\
\hline 9. & Export Import Bank of Bangladesh & 29. & Social Islami Bank Limited \\
\hline 10. & Limited & 30. & South Bangla Agriculture and Commerce \\
\hline 11. & First Security Islami Bank Limited & 31. & Southeast Bank Limited \\
\hline 12. & ICB Islamic Bank Limited & 32. & Standard Bank Limited \\
\hline 13. & IFIC Bank Limited & 33. & The City Bank Limited \\
\hline 14. & Jamuna Bank Limited & 34. & The Farmers Bank Limited \\
\hline 15. & Meghna Bank Limited & 35. & The Premier Bank Limited \\
\hline 16. & Mercantile Bank Limited & 36. & Trust Bank Bangladesh Limited \\
\hline 17. & Midland Bank Limited & 38. & Union Bank Limited \\
\hline 18. & Modhumoti Bank Limited & 39. & Uttara Bank Limited \\
\hline 19. & Mutual Trust Bank Limited & \\
\hline 20. & National Bank Limited & & \\
\hline
\end{tabular}

Source: Bangladesh Bank, 2015 and Wikipedia 
Table 3: General CSR Activities of Private Commercial Bank in Bangladesh

\begin{tabular}{|c|c|c|}
\hline Sector & Sub-Sector & $\%$ of Bank \\
\hline \multirow{7}{*}{ Education } & Scholarship & \multirow{7}{*}{80} \\
\hline & Seminar & \\
\hline & Workshop & \\
\hline & Infrastructural development & \\
\hline & Supporting to research & \\
\hline & Training & \\
\hline & Awards & \\
\hline \multirow{10}{*}{ Health } & Physical and mental & \multirow{10}{*}{70} \\
\hline & Reproductive & \\
\hline & Maternal & \\
\hline & Neonatal & \\
\hline & Nutrition & \\
\hline & Hygiene & \\
\hline & Sanitation & \\
\hline & Hospitals and Medical Services & \\
\hline & Training & \\
\hline & Infrastructure & \\
\hline \multirow{3}{*}{ Community Welfare } & Autism & \multirow{3}{*}{50} \\
\hline & Distressed \& Destitute Women Welfare & \\
\hline & Capacity Building & \\
\hline \multirow{6}{*}{ Women Empowerment } & Training & \multirow{6}{*}{20} \\
\hline & Financing & \\
\hline & Employment & \\
\hline & Awareness Building & \\
\hline & Encourage to Savings & \\
\hline & Entrepreneurship & \\
\hline Art \& Culture & & 75 \\
\hline Liberation War & Document and Publication & 10 \\
\hline Aid \& Assistance to Abroad & Nepal Earthquake & \\
\hline \multirow{5}{*}{ Socioeconomic Development } & Human Resource Development & \multirow{5}{*}{25} \\
\hline & Road & \\
\hline & Bridge & \\
\hline & Telecommunications & \\
\hline & Beautification & \\
\hline \multirow{2}{*}{ Sports } & Sponsorship & \multirow{2}{*}{78} \\
\hline & Infrastructure & \\
\hline \multirow{2}{*}{ Climate Change } & Disaster Management & \multirow{2}{*}{60} \\
\hline & Environment & \\
\hline
\end{tabular}

Source: Annual Report of Sample Bank in Different Years, *Multiple CSR Activities 